\title{
The use of "brutacaine" in children in emergency departments in Denmark
}

\author{
Michéle Lefort Sønderskov ${ }^{*}$, Peter Hallas ${ }^{\dagger}$ \\ From 4th Danish Emergency Medicine Conference \\ Roskilde, Denmark. 25-26 November 2011
}

\section{Background}

The physical restraint of children during painful procedures has been called "brutacaine". We sought to investigate if there was an un-met need for paediatric procedural pain management/sedation in Danish Emergency departments (EDs).

\section{Methods}

An online questionnaire was distributed to the leading nurses of the Eds. We chose to limit our inclusion to the 21 emergency hospitals in Denmark.

\section{Results}

The response rate was $81 \%(n=17)$. Of these, $71 \%(n=12)$ "often" or "sometimes" use physical restrain of children during procedures. Paediatric sedation is only possible in $29 \%$ of the EDs $(n=5) .29 \%(n=5)$ of the leading nurses stated that they at least once a month found there is a need for procedural sedation that their department is unable to provide. The three most commonly mentioned reasons for less than optimal pain management in the ER are: lack of subject specific education among the nursing staff of the EDs $(71 \%, n=12)$ and lack of training among the doctors on call in the EDs on paediatric procedural sedation $(53 \%, \mathrm{n}=9)$ as well as a need for local guidelines on the subject $(41 \%, n=7)$.

\section{Conclusion}

Physical restrain of children is a common event in Danish ED's. The findings indicate that there could be an un-met need for pain management during procedures in Danish EDs. Possible solutions could include guidelines on the subject, targeted education of ED staff and

\footnotetext{
* Correspondence: mlefort@gmail.com

+ Contributed equally

Anæstesiologisk Afd 4013, Juliane Marie Centret, Rigshospitalet, Denmark
}

increased local involvement of the anaesthesia department concerning pain management in the ED's.

Published: 16 April 2012

doi:10.1186/1757-7241-20-S2-P49

Cite this article as: Sønderskov and Hallas: The use of "brutacaine" in children in emergency departments in Denmark. Scandinavian Journal of Trauma, Resuscitation and Emergency Medicine 2012 20(Suppl 2):P49.
Submit your next manuscript to BioMed Central and take full advantage of:

- Convenient online submission

- Thorough peer review

- No space constraints or color figure charges

- Immediate publication on acceptance

- Inclusion in PubMed, CAS, Scopus and Google Scholar

- Research which is freely available for redistribution
C Biomed Central

\section{() Biomed Central}

